\title{
Is the tenofovir based therapy almighty for previous treatment failure in chronic hepatitis B?
}

\author{
Hyung Joon Yim \\ Division of Gastroenterology and Hepatology, Department of Internal Medicine, Korea University Medical College, Ansan, Korea
}

Keywords: Chronic hepatitis B; Tenofovir; Treatment failure; Resistance; Suboptimal

\section{See Article on Page 241}

During the past decade, management of drug resistant chronic hepatitis B (CHB) has been a major issue. ${ }^{1,2} \mathrm{~A}$ series of new antiviral agents has been developed, which provided new treatment options as well as new resistance issues. Hence, to avoid multidrug resistance, ${ }^{2}$ combination of antiviral agents without cross resistance has been recommended. ${ }^{3}$ However, combination of the less potent drug did not produce a better efficacy while the incidence of additional resistance has decreased. ${ }^{3-5} \mathrm{~A}$ more potent drug was needed for a better antiviral response. Tenofovir disproxil fumarate (TDF) is a nucleotide analogue which has a strong antiviral effect in treatment naïve as well as treatment experienced CHB patients for a long term periods. ${ }^{6,7}$ Also its therapeutic efficacy is much improved than that of adefovir (ADV). ${ }^{7}$ Therefore it is natural that combination therapy containing TDF show higher response rates than ADV-based therapies for management of drug resistance.

Previously, TDF plus ETV therapy was evaluated in Western countries, ${ }^{8}$ and subsequently in Korea as well (Table 1). ${ }^{9-11}$ This combination therapy showed a better virologic response compared with ADV plus ETV therapy in refractory or suboptimal responders to lamivudine (LMV) plus ADV combination in a retrospective study conducted in Korea (at 12 month, $84.8 \%$ vs. $26.7 \%$, respectively, $P<0.001) .{ }^{11}$ The study included $58.7 \%$ of multidrug resistant CHB patients. Single arm studies of TDF-ETV combination were reported with a retrospective and a prospective design in Korea. ${ }^{910}$ Virologic response was achieved in approximately $80 \%$ of patients within a year. Furthermore, the antiviral efficacy was not influenced by the type of prior therapies and baseline resistance mutations in both studies. ${ }^{9,10}$

In the current issue, Kim et al. introduced an interesting data regarding management of suboptimal responders to ETV-ADV combination therapy. ${ }^{12}$ They observed the patients for a long term period up to 3 years after initiating ETV-ADV combination therapy for LMV, ADV, and/or ETV resistance. In addition, the authors evaluated the responses of TDF based therapy which was introduced in case of refractory to the ETV-ADV combination. Among 48 patients enrolled, 12 patients achieved virologic response within 3 years, and 26 patients switched to the TDF based therapies due to suboptimal response despite long term ETV-ADV combination therapy. Ten patients received TDF monotherapy, of whom 9 achieved virologic response while 9 patients received TDF combination therapy (TDF-LMV in 7 and TDF-ETV combination in 2 patients), of whom 8 achieved virologic response. The authors subsequently performed in vitro susceptibility test using replicons

\section{Abbreviations:}

$A D V$, adefovir; CHB, chronic hepatitis B; ETV, entecavir; LMV, lamivudine; TDF, tenofovir

\section{Corresponding author: Hyung Joon Yim}

Division of Gastroenterology and Hepatology, Department of Internal Medicine, Korea University Ansan Hospital, 123 Jeokgeum-ro, DanwonGu, Ansan 15355, Korea

Tel: +82-31-412-6565, Fax: +82-31-412-5582

E-mail:gudwns21@medimail.co.kr

Received : May 6, 2016/ Revised : Jun. 10, 2016 
Table 1. Representative published data of tenofovir-based therapies from Korea for multiple treatment failures

\begin{tabular}{|c|c|c|c|c|}
\hline Target population (n) & Design & $\begin{array}{l}\text { Treatment } \\
\text { duration }\end{array}$ & Key Findings & $\begin{array}{l}\text { Author } \\
\text { Ref. No. }\end{array}$ \\
\hline $\begin{array}{l}\text { LMV+ADV-R (28), } \\
\text { LMV+ETV-R (45), and } \\
\text { LMV+ADV+ETV-R (20) }\end{array}$ & $\mathrm{RC}$ & 13 months & $\begin{array}{l}\text { Cumulative VR rates at } 6 \text { mon were } 55.7 \%, 75.0 \% \text {, and } 65.0 \% \text {, respectively, } \\
\text { by TDF-ETV combination. A lower baseline HBV DNA level was an } \\
\text { independent factor for VR, but resistance type was not. }\end{array}$ & $\operatorname{Lee}^{9}$ \\
\hline $\begin{array}{l}\text { Mixed of LMV, ADV, ETV-R } \\
(64)\end{array}$ & $P C$ & 48 weeks & $\begin{array}{l}\text { VR rate was } 85.9 \% \text { by TDF-ETV combination therapy. The combination is } \\
\text { highly efficacious. }\end{array}$ & Park $^{10}$ \\
\hline $\begin{array}{l}\text { Suboptimal responder to } \\
\text { LMV+ADV (63) }\end{array}$ & $\mathrm{RC}$ & 12 months & $\begin{array}{l}\text { VR rates were } 84.8 \% \text { vs. } 26.7 \% \text { by TDF-ETV vs. ADV-ETV, respectively. TDF- } \\
\text { ETV combination showed better response rate. }\end{array}$ & Park $^{11}$ \\
\hline $\begin{array}{l}\text { Mixed of LMV, ADV, ETV-R } \\
(52)\end{array}$ & $\mathrm{RC}$ & 18 months & $\begin{array}{l}\text { VR occurred in } 72 \% \text { vs. } 78 \% \text { of TDF-LMV vs TDF-ETV group, respectively. } \\
\text { No difference between the groups. }\end{array}$ & $\mathrm{Kim}^{14}$ \\
\hline $\begin{array}{l}\text { LMV-R+ADV-R (43) and } \\
\text { LMV-R+ETV-R (113) }\end{array}$ & $\mathrm{RC}$ & 15 months & $\begin{array}{l}\text { Cumulative VR rates were } 81.4 \% \text { (ADV-R) and } 84.1 \% \text { (ETV-R) by TDF } \\
\text { monotherapy. Multiplicity of resistance did not influence the VR. }\end{array}$ & $\operatorname{Lee}^{15}$ \\
\hline LMV+ETV-R (90) & $\mathrm{RCT}$ & 48 weeks & $\begin{array}{l}\text { VR rates were } 71 \% \text { vs. } 73 \% \text { in TDF monotherapy vs. TDF-ETV combination } \\
\text { groups. Efficacy of TDF monotherapy was comparable that of TDF-ETV } \\
\text { combination therapy. }\end{array}$ & $\operatorname{Lim}^{17}$ \\
\hline $\begin{array}{l}\text { LMV+ADV-R or } \\
\text { LMV+ADV+ETV-R (102) }\end{array}$ & $\mathrm{RCT}$ & 96 weeks & $\begin{array}{l}\text { VR rate was } 64 \% \text { in TDF monotherapy group and } 63.5 \% \text { in TDF-ETV } \\
\text { combination followed by TDF group. TDF monotherapy provided high } \\
\text { VR rate comparable to TDF-ETV combination therapy. }\end{array}$ & $\operatorname{Lim}^{18}$ \\
\hline
\end{tabular}

LMV, lamivudine; ADV, adefovir; ETV, entecavir; TDF, tenofovir; R, resistance; PC, prospective cohort; RC, retrospective cohort; $R C T$, randomized controlled trial; mon, month; VR, virologic response.

obtained from 4 patients. Interestingly, albeit weak, replication was detected in the case of TDF monotherapy while no replication was observed under TDF-ETV combination therapy.

In this study, the response rate of ETV-ADV therapy was relatively low (12 out of 48 patients in 3 years) in the patients with multiple lines of treatment failure as expected, and it is consistent with previous report. ${ }^{13}$ When comparing the TDF based therapies for ADV-ETV suboptimal responders, TDF monotherapy was efficacious and seemed not to be inferior to the TDF based combination therapies (90\% vs $89 \%$, respectively).

As mentioned above, the high efficacy of TDF-based combination therapy has been reported from Korea. ${ }^{9-11,14}$ However, several additional data comparing TDF monotherapy and TDF-ETV combination therapy highlighted that monotherapy is as efficacious as combination therapy even for multiple drug resistance (Table 1). . $^{15-18}$ For example, virologic response was achieved in $71 \%$ of patients with TDF monotherapy while in $73 \%$ of patients with TDF-ETV combination therapy $(P>0.99)$ after 48 weeks in the presence of ETV resistance. ${ }^{17}$ Likewise, in another prospective study which included ADV-resistant CHB patients, virologic response rate was $62 \%$ in the TDF monotherapy group after 96 weeks while $63.5 \%$ in the sequential 48-week TDF-ETV combination therapy and subsequent 48-week TDF monotherapy group $(P=0.88) .^{18}$ Also, type of resistant mutation did not significantly affect the outcome under TDF monotherapy. ${ }^{15,16}$ In contrast, there is a discrepancy between Kim et al's. ${ }^{12}$ in vitro study finding and these clinical data, in terms of incomplete suppression of mutant HBV by TDF monotherapy. The HBV mutant clones retained no known TDF-resistant mutation, but efficacy of TDF was limited. The sequences denoted only LMV-resistant mutations together with several multiple site amino acid substitutions of which the significance has not been proved. As we still don't have experience of TDF resistance in HBV mono-infected patients, so it would be worth evaluating effect of individual substitutions on viral replication fitness under various antiviral agents including TDF. Otherwise, it would be difficult to acknowledge the role of the substitutions found in the clones.

Clinical course of patients with drug resistance is troublesome, not only because of decreased virologic response, but also because of lack of serologic response. Most of the patients included in Kim et al. ${ }^{12}$ study were HBeAg positive, i.e. $97.9 \%$ in overall patients. As they mentioned, response guided therapy using HBsAg as well as HBeAg quantification could be helpful. In addition, immune responses may need to be boostered in a separate manner. For example, combination of pegylated interferon ${ }_{1}^{19}$ toll like receptor agonist, ${ }^{20}$ therapeutic vaccine, ${ }^{21}$ or other new emerging therapy might be helpful. Otherwise, end point of treatment will 
not be able to be reached in CHB patients who have experienced multiple drug resistance.

\section{Conflicts of Interest}

The author has no conflicts to disclose.

\section{REFERENCES}

1. Yim HJ, Hwang SG. Options for the management of antiviral resistance during hepatitis B therapy: reflections on battles over a decade. Clin Mol Hepatol 2013:19:195-209.

2. Yim HJ, Hussain M, Liu Y, Wong SN, Fung SK, Lok AS. Evolution of multi-drug resistant hepatitis $B$ virus during sequential therapy. Hepatology 2006;44:703-712.

3. Yim HJ, Seo YS, Yoon EL, Kim CW, Lee CD, Park SH, et al. Adding adefovir vs. switching to entecavir for lamivudine-resistant chronic hepatitis B (ACE study): a 2-year follow-up randomized controlled trial. Liver Int 2013;33:244-254.

4. Rapti I, Dimou E, Mitsoula P, Hadziyannis SJ. Adding-on versus switching-to adefovir therapy in lamivudine-resistant HBeAg-negative chronic hepatitis B. Hepatology 2007:45:307-313.

5. Peters MG, Hann Hw H, Martin P, Heathcote EJ, Buggisch P, Rubin R, et al. Adefovir dipivoxil alone or in combination with lamivudine in patients with lamivudine-resistant chronic hepatitis B. Gastroenterology 2004;126:91-101.

6. Kitrinos KM, Corsa A, Liu Y, Flaherty J, Snow-Lampart A, Marcellin P, et al. No detectable resistance to tenofovir disoproxil fumarate after 6 years of therapy in patients with chronic hepatitis B. Hepatology 2014;59:434-442.

7. Marcellin P, Heathcote EJ, Buti M, Gane E, de Man RA, Krastev Z, et al. Tenofovir disoproxil fumarate versus adefovir dipivoxil for chronic hepatitis B. N Engl J Med 2008;359:2442-2455.

8. Petersen J, Ratziu V, Buti M, Janssen HL, Brown A, Lampertico P, et al. Entecavir plus tenofovir combination as rescue therapy in pretreated chronic hepatitis B patients: an international multicenter cohort study. J Hepatol 2012;56:520-526.

9. Lee YB, Lee JH, Lee DH, Cho H, Ahn H, Choi WM, et al. Efficacy of entecavir-tenofovir combination therapy for chronic hepatitis $B$ patients with multidrug-resistant strains. Antimicrob Agents Chemother 2014;58:6710-6716.

10. Park JY, Kim CW, Bae SH, Jung KS, Kim HY, Yoon SK, et al. Entecavir plus tenofovir combination therapy in patients with multi-drug resistant chronic hepatitis B: results of a multicenter, prospective study.
Liver Int 2016 Jan 19. [Epub ahead of print]

11. Park JG, Park SY. Entecavir plus tenofovir versus entecavir plus adefovir in chronic hepatitis B patients with a suboptimal response to lamivudine and adefovir combination therapy. Clin Mol Hepatol 2015;21:242-248.

12. Kim JH, Ahn SH, Ko SY, Choe WH, Kim K-H, Kwon SY. The efficacy of tenofovir-based therapy in patients showing suboptimal response to entecavir-adefovr combination therapy. Clin Mol Hepatol 2016;22:241-249.

13. Lim YS, Lee TH, Heo NY, Shim JH, Lee HC, Suh DJ. Entecavir plus adefovir combination treatment for chronic hepatitis B patients after failure of nucleoside/nucleotide analogues. Antivir Ther 2012;17:5360.

14. Kim BG, Jung SW, Kim EH, Kim JH, Park JH, Sung SJ, et al. Tenofovirbased rescue therapy for chronic hepatitis B patients who had failed treatment with lamivudine, adefovir, and entecavir. J Gastroenterol Hepatol 2015;30:1514-1521.

15. Lee S, Park JY, Kim do Y, Kim BK, Kim SU, Song K, et al. Prediction of virologic response to tenofovir mono-rescue therapy for multidrug resistant chronic hepatitis B. J Med Virol 2016;88:1027-1034.

16. Kim HJ, Cho JY, Kim YJ, Gwak GY, Paik YH, Choi MS, et al. Longterm efficacy of tenofovir disoproxil fumarate therapy after multiple nucleos $(\mathrm{t})$ ide analogue failure in chronic hepatitis $\mathrm{B}$ patients. Korean J Intern Med 2015;30:32-41.

17. Lim YS, Byun KS, Yoo BC, Kwon SY, Kim YJ, An J, et al. Tenofovir monotherapy versus tenofovir and entecavir combination therapy in patients with entecavir-resistant chronic hepatitis B with multiple drug failure: results of a randomised trial. Gut 2016;65:852-860.

18. Lim YS, Yoo BC, Byun KS, Kwon SY, Kim YJ, An J, et al. Tenofovir monotherapy versus tenofovir and entecavir combination therapy in adefovir-resistant chronic hepatitis B patients with multiple drug failure: results of a randomised trial. Gut 2016;65:1042-1051.

19. Marcellin P, Ahn SH, Ma X, Caruntu FA, Tak WY, Elkashab M, et al. Combination of Tenofovir Disoproxil Fumarate and Peginterferon alpha-2a Increases Loss of Hepatitis B Surface Antigen in Patients With Chronic Hepatitis B. Gastroenterology 2016;150:134-144 e10.

20. Lanford RE, Guerra B, Chavez D, Giavedoni L, Hodara VL, Brasky KM, et al. GS-9620, an oral agonist of Toll-like receptor-7, induces prolonged suppression of hepatitis B virus in chronically infected chimpanzees. Gastroenterology 2013;144:1508-1517, 1517 e1-10.

21. Xu DZ, Wang XY, Shen XL, Gong GZ, Ren H, Guo LM, et al. Results of a phase III clinical trial with an HBsAg-HBIG immunogenic complex therapeutic vaccine for chronic hepatitis B patients: experiences and findings. J Hepatol 2013;59:450-456. 